\title{
Bordering on Conventional: The Politics of Iraqi Resettlement to the US and Europe, 2003-2011
}

\author{
Chantal E. Berman
}

\begin{abstract}
Of some 2.5 million Iraqi citizens internationally displaced in the wake of Operation Iraqi Freedom, less than 100,000 have achieved permanent international resettlement. This paper compares US and EU policies regulating the selection and admission of Iraqi refugees since 2003, focusing on the divergent political priorities and structural considerations underpinning variations in resettlement levels during this time. I argue that US resettlement of Iraqi refugees is primarily an element of foreign policy, defined by strategic objectives in Iraq and the surrounding region, whereas admissions to the EU reflect ongoing intra-European debates surrounding the construction and modification of the Common European Asylum System (CEAS). Whereas resettlement to the US increased drastically following a "strategic" reframing of the Iraqi refugee crisis in 2007, failures in the implementation of CEAS's "standardization" agenda, compounded by enhanced European restrictions on refugee movement, have limited Iraqi admissions to Europe during this time.
\end{abstract}

\section{Résumé}

Des quelques 2,5 millions de citoyens irakiens déplacés internationalement suite à l'Operation Iraqi Freedom, moins de 100000 ont réussi leur réinstallation permanente dans un autre pays. Cet article compare les politiques américaines et européennes réglementant la sélection et l'admission des réfugiés irakiens depuis 2003. On s'y concentre sur les différences de priorités politiques et de considérations structurelles qui sous-tendent les différences dans le nombre de réfugiés installés. On avance que l'installation des réfugiés irakiens aux États-Unis relève surtout d'une politique des étrangers définie par des objectifs stratégiques en Irak et au Moyen Orient. En comparaison, leur admission en Europe dépend des débats européens sur la construction et la modification du Régime d'asile européen commun (RAEC). Alors que les États-Unis accueillaient beaucoup plus de réfugiés irakiens suite à une refonte stratégique de leurs politiques en réponse à la crise des réfugiés de 2007, au même moment, les échecs dans la mise en place des objectifs standardisés du RAEC, de pair avec les restrictions européennes sur le mouvement des réfugiés, ont limité l'admission de réfugiés irakiens en Europe.

\section{Introduction}

June 2011 marked the 60th anniversary of the UN Convention relating to the Status of Refugees, which laid down protective standards for displaced Europeans in the post-war era and established refugee non-refoulement as a premier principle of contemporary international law. Along with its 1967 Protocol, the Convention has spawned a host of diverse legislation in signatory states ${ }^{1}$ pertaining to the selection and integration of foreign refugees. Individual resettlement policies vary widely in the number of refugees accepted annually and in the character of rights and services available to new migrants, and each national resettlement program is subject to a unique set of fiscal and political prerogatives.

Whereas the original European "refugees" found ample opportunities for life, work, and citizenship in the United States and Western Europe, their experience has been seldom replicated in the Convention's 60 -year history. Today's refugees-some 15.4 million of them worldwide, according 
to the United Nations High Commissioner for Refugees $(\mathrm{UNHCR})^{2}$-face first-world resettlement quotas that pale in comparison to demonstrated need. Iraqis who have fled personal and political violence since the American invasion of Iraq in 2003 are no exception.

Though accurate numbers are difficult to come by, the Congressional Research Service estimates that up to 2.5 million Iraqis have sought international refuge since 2003,3 with a vast majority still living precariously in Iraq's neighbouring states. Studies show that a preponderance of Iraqi refugees oppose returning to Iraq in the near future, ${ }^{4}$ and UNHCR has corroborated their position in several reports outlining the hardships of Iraqis who prematurely repatriate. ${ }^{5}$ Recent multinational aid programs ${ }^{6}$ have sought to ameliorate the living conditions of displaced Iraqis as they await a permanent solution, but as the ongoing sociopolitical costs of refugee hosting produce more restrictive policies in Syria and Jordan, Iraqis trapped in the region are becoming more vulnerable to marginalization and abuse. The challenge for the international community remains to permanently resettle those Iraqis who are unable to integrate locally and unwilling to return to Iraq.

In this article, I compare the Iraqi resettlement efforts of the United States and the European Union since 2003, highlighting divergence in the fundamental political priorities underpinning admissions quotas, asylum recognition criteria, and other policy choices impacting the admission of Iraqi refugees and asylum seekers. I argue that US resettlement of Iraqi refugees is primarily an element of foreign policy, defined by strategic objectives in Iraq and the surrounding region, whereas admissions to the EU reflect ongoing intra-European debates surrounding the construction and modification of the Common European Asylum System (CEAS). Whereas the reframing of Iraqi resettlement as a matter of "strategic interest" caused a drastic increase in US Iraqi admissions after 2007, persistent failures in the implementation of CEAS's "standardization" agenda, compounded by enhanced restrictions on refugee movement, have resulted in an overall stagnation of Iraqi admissions to Europe.

\section{The Strategic Dimensions of Resettlement: Iraqi Refugees and Foreign Policy in the US}

Accounting for some two-thirds of UNHCR's annual global resettlement, ${ }^{7}$ the United States Refugee Admissions Program (USRAP) is by far the world's largest third-country resettlement scheme. The US has been resettling Iraqis since the early 1990s, with over 100,000 resettled as of May $2011 ; 8$ 18,838 were accepted for resettlement in FY 2009, and another 18,016 arrived in FY 2010. ${ }^{9}$ Yet a review of Iraqi resettlement levels in the post-invasion era reveals a severe lull in resettlement levels corresponding with the apex of Iraq's civil war and the heights of the Iraqi emigration, precisely as wide refugee flows compounded by a scarcity of foreign aid and resettlement options forced major host states such as Syria and Jordan to shut their borders with Iraq. ${ }^{10}$ Explaining this seemingly counterproductive dearth of resettlement options at a time of mounting need requires an understanding of the ways in which US resettlement policy has traditionally been dictated by broader foreign policy goals.

America's unique position of relative geographical isolation and her consequent reliance on overseas refugee processing has allowed successive administrations to manage the nationalities, ethnic identities, educational backgrounds, and other qualities of refugees arriving on US shores. The US Executive Branch establishes yearly admissions quotas for each major sending state, making a refugee's nationality the single most important factor determining his or her chances of achieving US resettlement. Historically, the formulation of these quotas has relied heavily on an administration's perception of the strategic benefits of resettlement, which range from shaming the sending state to forestalling the spread of conflict via militant refugees. Resettlement programs during the Cold War prioritized refugees from communist countries in Eastern Europe and Asia while maintaining lower quotas for refugees of strategically unimportant wars in the Middle East and Africa. ${ }^{11}$ Similarly, the US admitted some 30,000 Iraqi opponents of the Ba'ath regime during the sanctions period in Iraq, ${ }^{12}$ at an average yearly resettlement rate far outstripping that of the 2003-2007 period.

Perhaps most importantly, US resettlement levels tend to correlate negatively with ongoing US military engagement in a particular sending state, regardless of the severity of the refugee crisis in question. It was not until after the US withdrawal from Vietnam that America began the process of resettling some 322,000 Indochinese refugees; ${ }^{13}$ likewise, resettlement from both Iraq and Afghanistan decreased significantly after the initial US invasions of those countries. ${ }^{14}$ Refugee resettlement (or a calculated lack thereof) remains one tool among many in the diplomatic and strategic arsenal of the United States on a global scale.

In this section, I discuss the foreign policy bias apparent in US policy towards Iraqi refugee resettlement since 2003, identifying a "reframing" of the refugee discourse towards one of strategic concern in 2007-2008, and finally analyzing structural problems that cause actual Iraqi arrivals to frequently fall short of stated quotas. 
US Admissions 2003-2007: The "Refugee Crisis" That Wasn't

The experimental nature of Operation Iraqi Freedom-and the purported applicability of regime change followed by state building as a model for future US engagements in the region-provided strong impetus for the Bush administration to downplay the humanitarian costs of the Iraq war. As Sanders and Smith of the Brookings Institution wrote in a 2007 article, "Addressing the Iraqi refugee crisis implies an acknowledgement that the US-led coalition and the Iraqi government have been unable to provide security within the country." 15 The Bush administration employed a strategy of public denial for as long as politically expedient: instead of applauding nearby states for providing safe havens, the Bush administration accused Syria of harbouring "insurgent terrorists," 16 implying that Iraqis fleeing the country were doing so for reasons other than personal safety. UN Ambassador John Bolton denied any correlation between Operation Iraqi Freedom and the Iraqi refugee crisis; ${ }^{17}$ administration officials responded to criticism of this position by explaining that Iraqi displacement "predates the current conflict." 18 Funding followed suit; in 2007, the US spent just under \$200 million on displaced Iraqis-less, as Sanders and Smith pointed out, than the roughly $\$ 280$ million spent per day on the Iraq war. ${ }^{19}$

Despite dire UNHCR predictions to the contrary, the initial invasion of Iraq failed to produce more than several thousand refugees, mainly wealthy ex-Ba'athists fleeing in comfort to Syria, Jordan, and the Gulf States. ${ }^{20}$ Outflow of Iraqis increased in response to US operations in Fallujah in 2004 and peaked dramatically in 2006 and 2007, as large portions of Iraq disintegrated into sectarian violence following the bombing of the al-Askari mosque in Samarra. ${ }^{21}$ US Iraqi resettlement efforts during this period of increasing crisis can be characterized by a general dearth thereof: only 66 Iraqis were resettled in 2004, 198 in 2005, 202 in 2006 , and 1,607 in 2007. ${ }^{22}$

Ironically, the category of "refugee" was invoked repeatedly in early humanitarian justifications for the Iraq war via the trope of "return"-the post-war repatriation of some 60,000 Iraqi refugees from the 1980s and 1990s. ${ }^{23}$ The relative invisibility of Iraqi flight during the immediate postwar period allowed the US to focus its refugee-management faculties on these "returnees," who tended to align themselves politically against the Ba'ath regime. Until 2006, State Department funding for displaced Iraqis prioritized returnees over Iraqis remaining in or fleeing to nearby states. ${ }^{24}$ Moreover, Iraqi "return" lent legitimacy to the common anti-resettlement argument of "brain drain," the idea that displaced Iraqis should not be removed from the region lest their skills and expertise become permanently unavailable to the faltering Iraqi state-building project. $^{25}$ The US government's preferred solution for Iraqi refugees residing in neighbouring Arab countries has always been eventual repatriation, an option that is less costly in financial and political terms than large-scale Iraqi resettlement to the United States. ${ }^{26}$

Finally, the US refused until 2009 to send resettlement representatives to Syria, which has hosted a plurality of internationally displaced Iraqis since $2003 .{ }^{27}$ Ongoing discursive combat between the US and the Syrian state during the early 2000s-possibly compounded by the suspicion that Iraqis in Syria are more sympathetic to Ba'athist and anti-American platforms-resulted in strikingly low admissions from Syria proportionate to the number of refugees residing there. Department of Homeland Security (DHS) officials rejected "an unusually high percentage" of UNHCR referred refugees from Syria in 2007 without explanation, including 70 percent of women deemed in need of priority resettlement. ${ }^{28}$ Of 1,608 Iraqis resettled to the US that year, only 242 came from Syria. ${ }^{29}$

During the 2003-2007 period, the US did resettle handfuls of Iraqis with professional links to the US government by way of a translator relocation project active in both Iraq and Afghanistan. These early admissions were justified in terms of maintaining US access to Iraqis with vital language skills; as US Ambassador to Iraq Ryan Crocker explained, a dearth of US assistance to former translators, contractors, and fixers meant that fewer Iraqis would be willing to work with the US in the future. ${ }^{30}$ Yet these programs suffered from severe administrative disarray-refugees were often asked to verify their service with documents to which they had no legal access ${ }^{31}$-and from the extensive Homeland Security protocols that prevented many refugees of Middle Eastern and Central Asian origin from reaching the US during the early $2000 \mathrm{~s}^{32}$ The "enhanced security review" established for Iraqis in 2003 was so exhaustive, and the percentage of Iraqis deemed "inadmissible" so large, that UNHCR briefly stopped referring Iraqis to the United States. ${ }^{33}$ The "securitization" of US Iraqi resettlement in the immediate post-invasion period both compounded the general scarcity of resettlement places and justified it, by promulgating a view of Iraqi refugees as potential arbiters of conflict and terrorism. The concept of Iraqi refugee "rights" remained submerged in this discourse of "security" for several years onward, with detrimental effects on Iraqi admissions quotas to the United States.

\section{US Admissions 2008-2011: The Strategic Imperative of Iraqi Resettlement}

By the end of 2007, political pressure was mounting on the Bush administration to make broad changes to its policy of 
minimal action regarding Iraqi refugees. Numerous highprofile journalistic and NGO reports emerged on the crisis, and refugee advocates in major research institutions argued for a special US responsibility to Iraqi refugees, above and beyond standard levels of funding and resettlement allocated to other crises. ${ }^{34}$ Meanwhile, leading members of the newly Democratic Congress and Senate sought to reframe American political discourse on Operation Iraqi Freedom by initiating a series of committees examining its full range of humanitarian fallout. The refugee issue was front and centre. Invited to testify before Congress in late 2007, Director of Human Rights Watch's Refugee Division Bill Frelick charged George Bush with abandoning the presidential tradition of incorporating refugee resettlement into cus tomary displays of American moral leadership on a global level. Addressing the resources already allocated to certain groups of Iraqi refugees, Frelick stated bluntly:

Band-aid assistance and token resettlement might make Americans feel less guilty about the destruction and suffering this war has caused, but it will not be sufficient to make a difference in saving the lives of the vast majority of innocent civilians whose lives are still at risk. ${ }^{35}$

Yet accompanying this framework shift in the terms of US humanitarian responsibility was a sharp discursive recourse to the vocabulary of American interest and regional security. The prevalent concept of displaced Iraqis as a regional "conflict contagion,"36 however inaccurate in terms of actual violence perpetrated by these refugees, drove home the potential of the refugee crisis to further endanger the Iraqi state-building process by destabilizing nearby countries, threatening US cooperation with their governments, and providing an ample recruitment pool for would-be insurgents. A bipartisan Iraq Study Group chaired by James Baker and Lee Hamilton warned that "Iraq and the region could be further destabilized" if immediate action was not taken to address the refugee crisis, ${ }^{37}$ and UNHCR officials pleaded that rising volatility in Syria and Jordan stemmed from a lack of international burden-sharing assistance. ${ }^{38}$ The Refugee Crisis in Iraq Act, introduced by the late Senator Edward Kennedy in June 2007, cited the Baker-Hamilton conclusion and added: "If [refugees'] needs are not quickly and adequately met, these populations could become a fertile recruiting ground for terrorists." 39 By framing the Iraqi refugee crisis as a potent source of instability at a time when Iraq's civil war was just beginning to subside, refugee advocates found a strategic justification for Iraqi resettlement that resonated with the crisis-control tactics being deployed on the ground in Iraq. Resettlement once again became a diplomatic and strategic tool, rather than an under-resourced humanitarian sideshow.

Signed into law in February 2008, the Refugee Crisis in Iraq Act included several measures to increase and expedite US resettlement of Iraqi refugees. In addition to raising resettlement ceilings for Iraqis in general, the bill authorized 5,000 annual Special Immigrant Visas (SIV), intended to cover US-affiliated translators and contractors. Although the program has struggled to meet its quotas-641 visas were processed in FY 2008, and 3,028 in FY 2009-SIV admissions levels have been significantly higher than those of previous translator relocation initiatives. ${ }^{40}$ The US also established Overseas Processing Entities (OPE) in Egypt, Jordan, and Iraq-later to be supplemented with offices in Turkey, Lebanon, and Syria ${ }^{41}$ _ such that US-affiliated Iraqis as well as families of special humanitarian concern could apply directly to the United States without passing through an external referent such as UNHCR. ${ }^{42}$ Although limited in capacity, the OPE office in Baghdad eliminates the need for certain well-placed refugee applicants to exit Iraq, an act that has become increasingly difficult due to the restrictive border policies of nearby states. Iraqi resettlement increased nearly tenfold between 2007 and 2008, with 13,822 Iraqis making up nearly 23 percent of all US refugee admissions that year. ${ }^{43}$ As of May 2011, 58,811 Iraqis had been admitted under the Refugee Crisis in Iraq Act. ${ }^{44}$

Lacking the previous administration's imperative to defend US actions in Iraq, President Obama's statements on the Iraqi refugee crisis have echoed the Baker-Hamilton report, ${ }^{45}$ blending humanitarian imperative with recognition of strategic benefits. Newly elected, he referred to Iraqi refugees as "living consequences of this war," stating that "America has a strategic interest-and a moral responsibility-to act."46 The Obama administration's cautious reconciliation with Syria has also resulted in increased cooperation on behalf of Iraqi refugees, including the establishment of an OPE office in Damascus. While repatriation remains the US government's preferred solution for Iraqi refugees, official reports have begun to reference UNHCR's declarations that Iraq is not yet safe for large-scale return. According to the State Department's 2011 Proposed Refugee Admissions report, “The long term US strategy for Iraq's displaced is to help Iraq develop the capacity to reintegrate returning Iraqis into stable neighborhoods, while maintaining resettlement for the most vulnerable" 47

Problems remain, however, in the selection and integration of these "most vulnerable" due to ongoing structural inefficiencies in US Iraqi resettlement. Although "security" procedures for certain Iraqis-namely SIVs-were relaxed in 2007, the DHS continues to spar with the State Department's Bureau of Population, Refugees and Migration 
(PRM) over the admissibility of certain Iraqis, resulting in an average processing period of 10 months. ${ }^{48}$ According to a Government Accountability Office report, USRAP lacks capacity for strategic planning as well as a mandate to demand any streamlining of the security vetting process. ${ }^{49}$ Furthermore, USRAP bases its distribution of funds on past refugee flows, rather than present or projected ones; ${ }^{50}$ funding levels in 2008 and 2009 therefore reflected the far lower Iraqi resettlement quotas of 2006 and 2007,51 to the obvious detriment of the Iraqi admissions program. The US economic crisis and subsequent austerity measures have also affected USRAP, with the US FY 2010 budget allocating fewer funds for Migration and Refugee Assistance than the FY 2009 budget. ${ }^{52}$

As a result of these ongoing problems, scale-backs of target resettlement levels have been common in the post-2007 era. In FY 2009, for example, the US government issued only 2,389 SIV visas out of an authorized $11,050 .{ }^{53}$ The fiscal and organizational sloppiness of Iraqi refugee admissions to the US implies that despite amended intentions visà-vis the humanitarian fallout of Operation Iraqi Freedom, Iraqi refugee resettlement has remained a secondary priority, trumped by the ongoing financial and human resources allocated to US engagement in Iraq and Afghanistan. And as critics of US resettlement are quick to point out, USRAP admissions have yet to make a sizable dent in the refugee crisis for which, they argue, the US maintains ultimate responsibility. As of 2010, Iraqis constituted the second largest refugee group worldwide, second only to displaced Afghanis. ${ }^{54}$

\section{A "Race to the Bottom" or a Race to the Border? European Resettlement of Iraqis under CEAS}

Whereas nearly all Iraqi refugees reach the United States by virtue of resettlement initiatives, ${ }^{55}$ UNHCR referrals and other overseas processing programs account for a small minority of European admissions from the MENA region. A large majority of Iraqis reach Europe by land or sea, ${ }^{56}$ claiming asylum according to regulations set forth by individual states and by a series of EU directives pertaining to where, when, and on what grounds Iraqis may achieve refugee status. Iraqis have been seeking European asylum in large numbers since the $1990 \mathrm{~s},{ }^{57}$ and have comprised Europe's largest group of asylum seekers since 2007, accounting for some 38,000 or 17 percent of all applications. ${ }^{58}$

The 2003 dismantling of Saddam Hussein's regime had little immediate impact on previous European policies of Iraqi asylum and resettlement, which have long remained a subset of Europe's interior policy rather than its foreign relations. With the possible exception of the UK, the contemporary Iraqi refugee policies of EU states reflect far less on the politics of regime change in Iraq than on the structural complexities and intra-European debates surrounding the construction of the Common European Asylum System. Inaugurated in 1999, the CEAS regime intends to increase burden-sharing among EU Member States through the "liberalization" and "harmonization" 59 of their individual refugee protection standards, and to facilitate cooperation in regulating the movements of refugees into and around Europe. ${ }^{60}$ The past decade of EU resettlement policy can be characterized as an era of experimentation within these dual imperatives of liberalization and control, with Iraqi refugees serving as preliminary test subjects.

Some scholars of asylum have characterized European refugee policies in the contemporary era as a "race to the bottom," 61 arguing that the 1986 evisceration of Europe's internal borders set in motion a long-term process of states re-establishing population control by alternative means. By this logic, states that have lost the sovereign capacity to control population movement through their borders establish indirect methods of limiting migration, such as restrictive asylum criteria and low social benefits for non-Europeans. As states compete to redirect refugees towards their neighbours, their policies become more and more illiberal, leaving asylum seekers with limited prospects for resettlement and integration. Other scholars have extended this line of questioning towards skepticism about the principles of CEAS, arguing that any "harmonized" multi-state asylum regime will eventually achieve the lowest common denominator, as states that are unfit or unwilling to reform their asylum policies drive common protective standards ever lower. Satvinder S. Juss has described this shift as one "from uncoordinated liberalism to harmonized restrictionism." 62

Some evidence from the experience of Iraqi refugees in Europe supports these arguments, particularly the resettlement trajectory of Sweden, which has dismantled its exemplary Iraqi admissions program due in large part to the perceived burden-sharing failures of its neighbours. Indeed, UNHCR recently reported that "the relative importance of Europe as a destination for asylum-seekers has declined in recent years," citing a precipitous drop in Europe's share of asylum applications worldwide from 60 percent in 2005 to 45 percent in 2009.63 But as I argue in the following sections, the present state of the European refugee regime does not corroborate flaws in the theory of asylum policy integration so much as it reflects on CEAS's uneven implementation, where failures in the enforcement of "liberalization" coupled with an overt focus on "control" have narrowed the traditional options of asylum seekers prior to the fruition of sustainable alternatives.

In the following sections, I will detail the effects of standardization procedures and territorial control initiatives on 
Iraqi asylum seekers since 2003. I argue that intra-European cooperation has been more effective in the latter category, with consequently greater impacts on prospects for Iraqi resettlement in Europe. I then review nascent European efforts to "externalize" refugee policy along US lines by prioritizing overseas refugee processing-as opposed to the traditional European model of processing asylum seekers after their arrival to EU territory-and by employing foreign policy tools to impact the number of refugees arriving at Europe's borders.

\section{Standardized and/or Liberalized? Iraqi Refugees and Asylum Policy Harmonization}

In keeping with the agenda of asylum liberalization, the European Parliament supports the prima facie refugee status bestowed by UNHCR on refugees from southern and central Iraq. A 2007 resolution centred on improving the reception of Iraqis in Europe and standardizing EU Iraqi refugee response protocol called on Member States to "[o] vercome their position of non-action regarding the situation of Iraqi refugees and to fulfill their obligations under international and community law to give Iraqis in Member States the opportunity to lodge asylum applications."

Yet Iraqi recognition rates since the height of the crisis have varied widely, from some 82 percent in Sweden and 85 percent in Germany to 13 percent in the UK and less than 1 percent in Slovenia and Greece. ${ }^{64}$ Resettlement levels and percentages tend to be highest in Nordic states, while southern and eastern European states reject far more applicants than they resettle. Britain presents a somewhat unique case, based both on its active involvement in the Iraq war and on its sensitivity to projects of European policy harmonization. ${ }^{65} \mathrm{UK}$ asylum recognition rates are far lower than those of other European states within the same wealth bracket, and the UK's translator relocation program is far weaker than Denmark's, which admitted nearly 100 percent of its quota within a year following the Danish withdrawal from Iraq. ${ }^{66} \mathrm{EU}$ directives pertaining to policy harmonization allow "a wide amount of discretion and flexibility in a large number of areas," 67 noting ongoing variation in recognition criteria, in the condition of detention centres and hosting facilities, and in refugee access to employment. In short, Member States continue to base their Iraqi asylum policies on unique national priorities rather than the EU agenda of "harmonization" and "liberalization"; while some are unilaterally liberal, others fall short. A 2011 report by the European Council on Refugees and Exiles expressed acute disappointment with CEAS's harmonization progress, describing the current state of asylum in Europe as "not the progress that we hoped for." 68
The recent history of Sweden's Iraqi asylum regime demonstrates the ongoing failure of asylum policy harmonization in Europe and its corrosive effects on states with generous admissions policies. ${ }^{69}$ Sweden by 2006 had granted protection to more Iraqis than all other Member States combined, ${ }^{70}$ earning a reputation as Europe's most generous country of Iraqi asylum. Sweden was also foremost among European governments urging fellow Member States to liberalize their own asylum policies so as to spread the burden of asylum processing more evenly. ${ }^{71}$ When these calls went unheeded, Swedish officials spoke out against the idea that Swedish policy is "more liberal" towards Iraqis than other European states, complaining that the resulting "pull factor" had caused asylum applications in Sweden to rise to unmanageable levels. ${ }^{72}$ Policy modifications followed; a 2008 ruling established that Iraqis had to prove individual persecution in order to qualify for Swedish resettlement, driving Sweden's recognition rate for that year down to 40 percent. $^{73}$ From 2007 to 2009, Sweden's share of Iraqi resettlement in Europe dropped from 64 percent to 13 percent, ${ }^{74}$ a trend attributed by UNHCR to "a drop in recognition rates and a potential shift in flows from Sweden to its neighbors."75 Sweden continues overseas resettlement of Iraqis on a relatively generous scale, ${ }^{76}$ suggesting that Stockholm is not opposed to admission of Iraqis per se but has rather sought to counteract the pull factor driving Iraqis in Europe to set their sights on Sweden alone.

The apparent failure of CEAS to "trim national influence" 77 in asylum policy can be attributed to the weakness of positive measures intended to incentive harmonization. The European Asylum Support Office (EASO) facilitates informational exchange and practical cooperation among states already keen on Iraqi resettlement, but cannot take a role in the decision-making processes of individual states. ${ }^{78}$ The European Resettlement Fund (ERF), from which Member States can request up to 4,000 euros per head to assist in resettlement costs, ${ }^{79}$ has also proved too weak to incentivize more protective policies. Eiko R. Thielemann calls the ERF "symbolism rather than substance," a small consolation prize for Europe's southern and border states, many of which oppose asylum policy harmonization. ${ }^{80}$ Moreover, asylum seekers in Europe contend with post-9/11 security protocols that mirror American laws in language and effect, such as a December 2001 ruling requiring Member States to vet asylum applicants "for the purpose of ensuring that the asylum seeker has not planned, facilitated or participated in the commission of terrorist acts." 81 The elasticity of this law as it pertains to Iraqi migrants has allowed several European states-including both wealthy governments such as the UK and less resourced ones such as Greece-to justify the indefinite detention of Iraqis under auspices of the "vetting" 
process. ${ }^{82}$ CEAS's institutions lack the enforcement capacity to intervene.

\section{The Territorial Prerogative: Iraqi Refugees and Europe's Borders}

Whereas the US maintains de facto territorial control visà-vis inflows of Iraqi refugees, Europe's geographical proximity to the Middle East and its uniquely porous internal borders have shaped a strong European concern with controlling the physical movement of migrants and asylum seekers into and around Europe. A central goal of CEAS is to enhance collective control of Europe's peripheral borders such that the weak law-enforcement systems of southern European states might cease to facilitate unregulated entry to the EU. Further initiatives have focused on forestalling "secondary movements" 83 of asylum seekers between Member States, both positively (through the harmonization efforts described in the previous section) and through prohibitive regulations on refugee movement. Reduced access to European territory and reduced movement within Europe are therefore two of the greatest factors shaping the experiences of Iraqi asylum seekers in Europe.

Numerous studies of CEAS have found greater concentrations of fiscal and organizational resources allocated to "control" initiatives as opposed to "harmonizing" ones. ${ }^{84}$ Europe continues to strengthen the mandate of FRONTEX, its border control agency, in terms of patrolling capacity, detention facilities, and cooperation with the security forces of states such as Turkey, a major country of transit for Iraqis en route to Europe. ${ }^{85}$ The EC has also launched regional cooperative border patrols such as RABIT, a coalition of guards from Member States gathered in 2010 to assist the Greek government in forestalling "illegal" migration. ${ }^{86}$ Both FRONTEX and RABIT lack specific mandates vis-àvis the recognition of asylum seekers, leading rights groups to speculate about violations of Iraqi non-refoulement on Europe's borders. Amnesty International in 2009 reported on FRONTEX's "targeting" of Iraqi “illegal migrants," implying that contrary to the European Parliament's support for prima facie status, at least some Iraqis are not being considered as asylum seekers upon arrival to Europe's borders. ${ }^{87}$

Europe has also expanded its means of deterritorialized migration control, including complicated visa regulationsto enter Europe legally, Iraqis need a G-series passport only available in Baghdad ${ }^{88}$ - and fines for airline carriers transporting unregistered migrants to Europe. ${ }^{89}$ Aside from outsourcing the preliminary steps of the asylum recognition process to foreign bureaucracies and private companies, these control mechanisms have resulted in an incremental "criminalization" of asylum seeking, where refugees often have to break the law in order to reach Member States where they can claim asylum. ${ }^{90}$ While international refugee law contains no specific language prohibiting either of these regulations, policies that conflate UN-recognized asylum seekers with illegal migrants violate the non-penalization clause of the Refugee Convention, which obliges states not to "impose penalties, on account of their illegal entry or presence, on refugees who ... enter or are present in the territory without authorization." 91 Application levels to Europe in the late 2000s have reflected the increasing difficulty of reaching European territory. From 2009 to 2010, Iraqi asylum applications to EU states dropped by 19 percent. $^{92}$

Foremost among EU policies regulating the internal movement of Iraqi asylum seekers is the Dublin II regulation, which stipulates that a refugee must apply for asylum to the European country in which he or she first sets foot, and allows Member States to deport asylum candidates back to their original state of entry. Dublin II was introduced in 2005 to counteract the phenomenon of "asylum shopping"where refugees travel through Europe in search of a hospitable asylum regime-thereby counteracting the magnet effect of liberal regimes such as Sweden's. In reality, Dublin II has increased pressure on the weak asylum regimes of Europe's southern and border states, where protection standards have fallen even lower as a result of functioning overcapacity.

Opponents of the Dublin II regime cite the case of Greece, whose border with Turkey and 18,400 kilometres of coastline are major points of entry for Iraqis seeking EU asylum. Dublin II's implementation caused a major surge of asylum applications to Greece; levels increased by 105 percent from 2006 to 2007, at a time when applications to Europe overall rose only 11 percent. (Out of 25,000 applicants to Greece in 2007 , some 5,500 were Iraqi. ${ }^{93)}$ The EASO has attempted to improve Greece's protective standards and its asylumprocessing capacity using a volunteer team of Member State "consultants," while the RABIT program has somewhat successfully decreased the number of asylum seekers for whom Greece is the initial point of entry. ${ }^{94}$ Yet Greek recognition rates for Iraqis continue to hover below 1 percent, ${ }^{95}$ and a series of high-profile NGO reports have condemned the ongoing detention, deportation, and abuse of Iraqis and other refugees in Greece. ${ }^{96}$ Little more than five years into Dublin II's lifespan, both UNHCR and the European Court of Human Rights have issued statements urging Member States to suspend the transfer of asylum seekers to Greece. (Norway, Sweden, and Finland had already begun doing so of their own accord. ${ }^{97}$ ) Collaboration in the prevention of Dublin II deportations to Greece is a small yet welcome sign of protective "harmonization" among EU states, but one 
which nonetheless highlights the failure of CEAS and the EASO to effect liberalization in the most dire of scenarios.

According to the ECRE, Dublin II is "based on the myth that protection standards are equivalent throughout the EU," 98 in which case an asylum seeker's obligation to apply to one state or another would have little bearing on his chances of achieving refugee status. Yet Dublin II's premature application to Europe's present-day asylum system effectively mandates asylum applications to states with clear records of migrant abuse. Dublin II epitomizes CEAS's misguided implementation, where burden-sharing mechanisms based on the restriction of refugee movement-rather than the reform of Member State policies-result in the deterioration, rather than liberalization, of refugees' rights in Europe. Just as border control initiatives "criminalize" the process of arriving to Europe, Dublin II puts the onus on refugees, rather than governments, to effect greater equilibrium in application levels among European states.

\section{Whither Asylum? Iraqi Refugees and "Externalization"}

Despite Europe's long-standing reputation as a continent of asylum rather than overseas processing and resettlement, the border-tightening measures discussed above as well as recent initiatives in overseas processing may suggest a grad ual shift in Europe's refugee policy towards the American model. 99 The prospect of "externalizing" European refugee policy has gained traction among policy makers who view overseas processing and foreign policy action to address "root causes" of refugee flows as alternatives to a liberal European asylum regime. 100 "Externalization" holds both positive and negative possibilities for the rights of Iraqi refugees in Europe. While it is still too early to determine whether this nascent trend will take root, it is fair to say that the outcomes of "externalization" will depend, like CEAS, on the means and the priorities by which it is implemented.

Recent European resettlement initiatives have framed extraterritorial processing-European missions mimicking the US OPE offices-as a proactive substitute for open borders, one which would establish greater control over levels of Iraqis and other refugees in the European processing system. ${ }^{101}$ Direct resettlement from host states such as Syria and Lebanon has indeed increased since the onset of the crisis; whereas 8 Member States admitted 3,300 Iraqis in 2007 and 2008 combined, 12 EU countries offered 5,100 resettlement spots in 2009 alone. ${ }^{102}$ Following a 2008 Justice and Home Affairs Council decision that Member States should jointly resettle 10,000 Iraqi refugees "on a voluntary basis," 103 several states with no prior Iraqi resettlement programs began accepting UNHCR referrals. During that same year, Germany and France signed ad hoc agreements with UNHCR, agreeing to resettle some 500 to 2,000 Iraqis each according to specific criteria laid out by those governments. Both states initially expressed preference for "minority" Iraqis, though they amended this criterion to focus on the "most vulnerable," such as female-headed households. ${ }^{104}$ The growing European preference for joint resettlement programs, rather than asylum policy harmonization, points to a desire for greater control over the Iraqi admissions process. States can maintain individualized admissions criteria while cooperating on the structural level to facilitate the selection and transportation of refugees.

The popularity of multilateral interventions in the early 1990s raised the prospect of "prevention" as an element of refugee policy, where Western states would act preemptively to halt refugee-producing conflicts before the onset of mass emigration. ${ }^{105}$ While policy formulation along the lines of "prevention" has always been limited, the use of foreign aid, bilateral agreements, and other foreign policy tools to preclude refugee movements remains a popular principle in European thought, if not an active one in European policy. Foreign aid to Syria and Jordan to assist in provision for displaced Iraqis predates the Joint Resettlement Initiative by several years, ${ }^{106}$ though at levels insufficient to impact the need for third-country resettlement. Other bilateral initiatives of a more manipulative nature provide fiscal support to the border fortification programs of major refugee sending states; prior to the 2011 NATO action against the Gaddafi regime, for example, several European states were conducting negotiations with Libya over a framework agreement to stop seaborne departures to Europe. ${ }^{107}$ Such partnerships under the guise of "externalization" have prompted rights groups to challenge the direction of Europe's refugee and asylum policy, accusing the EU of seeking to sequester asylum seekers abroad regardless of the validity of their claims.

\section{Conclusion: Asylum, Resettlement, and the Future of Iraq's Refugees}

Aside from highlighting divergence in their political positionalities vis-à-vis Iraq and the surrounding region, comparing US and EU Iraqi refugee admissions demonstrates the structural dissimilarity between in-country asylum systems and resettlement via overseas processing. "Resettlement" is a top-down process that facilitates the political manipulation of refugee flows; admissions levels can very easily be expanded, decreased, or halted altogether, as the United States has done vis-à-vis Iraqis since the 1990s. Asylum, by comparison, is messy. The relatively open borders that characterize asylum systems diminish host-state control over the numbers, nationalities, and other characteristics of potential new residents, and raise difficult questions about the legal status of failed asylum seekers 
who remain in host-state territory. States that liberalize their asylum policies can find themselves overwhelmed by unregistered migrants, whose claims upon the state necessitate an independent infrastructure of courts, bureaucracy, and hosting facilities. The fiscal and sociopolitical cost of asylum can grate harshly on the tolerance of host state populations; Sweden's election of a right wing, anti-migrant government in 2006 provides a stark example. If US decisions regarding Iraqi refugee admissions seem comparatively straightforward, it is because resettlement via overseas processing allows for a unique level of state control over the refugee admission process.

Yet asylum as an institution more closely mirrors the goals of the UN Refugee Convention, where the right of persecuted individuals to cross international borders is not contingent on the political whims of a particular host state. The comparative visibility of refugees in asylum systems obliges action on the part of the host state, whereas states that practice overseas processing only can easily ignore mounting need in remote places such as Syria, Lebanon, and Jordan, states whose refugee-to-population ratios are some of the highest on earth. The Bush administration's deliberate blind eye towards Iraqi refugees from 2003 through 2007 exemplifies the easy subjugation of refugee rights to host-state interests in systems of overseas resettlement. Had a handful of European states not maintained generous asylum policies for Iraqis during these years, options for Iraqi resettlement worldwide would have been scarce indeed.

For these reasons, the growing European preoccupation with border fortification and deterritorialized migrant control is a worrisome trend. Though the referenced "liberal European asylum tradition" is somewhat mythological, Europe has historically served as an important site of asylum for refugees that the US has not considered strategically important. A prospective lockdown on Europe's peripheryto say nothing of partnerships aimed at sequestering asylum seekers in states with known records of migrant abuseheralds an effective end to European asylum. As the ECRE points out, "The best protection regime will be of little use if refugees are unable to reach the EU's territory."108 Though it remains unclear whether "externalization" will overtake asylum as Europe's primary model of refugee management, it is certain that overseas processing will have to increase dramatically if the overall effects of externalization are not to be severely deliberalizing.

Doing justice to the topic of Iraqi asylum in the EU requires investigating the unprecedented effects of the Single Europe Act on the concept of territorial sovereignty in Europe and on corresponding regimes of migration and asylum. Some view the CEAS's failure to "harmonize" European asylum as a referendum on European territorial integration, where previously unilateral choices relating to migration and resettlement have become a de facto point of intra-European tension and debate. The CEAS framework institutionalized these debates rather than resolving them, and the decisive lack of "harmonization" progress during the program's inaugural decade speaks to the tenacity with which many Member States seek to maintain individual policies of asylum.

Achieving burden sharing in the Schengen context requires both facets of CEAS “cooperation"; Europe's peripheral border must be regulated (though not closed off), and asylum policies must be integrated (if not harmonized) to avoid future asylum shutdowns such as Sweden's. Yet comparing the impact of institutions such as the European Refugee Fund with regulations such as Dublin II reveals the weakness of the CEAS's "liberalization" and "harmonization" measures as compared to their control-oriented counterparts. Moreover, the underwhelming outcome of EASO's intervention in Greece demonstrates that harmonization initiatives without enforcement mechanisms have little possibility of success. Many scholars pay homage to the "norm of protection"109 promulgated by European institutions, but that norm's bearing on the experience of refugees is strictly a matter of implementation.

Finally, comparing US and EU policies vis-à-vis Iraqi refugees raises questions about states' accountability for refugee-producing policies, and about the corresponding levels of aid and resettlement required to offset this "responsibility". While Europeans opposed to Iraqi resettlement have argued that the US should have sole responsibility for Iraqis' humanitarian needs, Bush officials have justified policies of minimal resettlement through a causational delinking of the US invasion and the ensuing refugee crisis. The ambiguity of "responsibility" for refugee crises may be one reason why the UN Refugee Convention places no onus on "responsible parties" to shoulder the burden of refugee aid and resettlement alone. Indeed, "burden-sharing" favors the even distribution of refugee hosting among Convention signatory states-according to capacity, and without any consideration of guilt.

Still, it is worth re-examining the arguments of US refugee experts who were able to transpose demands for a "special responsibility" towards recognition of a "particular interest" in Iraqi resettlement. As the primary international party invested militarily and financially in the flailing Iraqi statebuilding project, the US has finally become-as it should have been from the outset-foremost among states working towards the gradual resolution of the Iraqi refugee crisis. As evidenced by the resettlement of nearly 100,000 refugees per year in the 1990s, ${ }^{110}$ the United States has extremely high capacity for refugee absorption. While organizational 
failures can determine the frequency with which US administrations meet their own resettlement objectives, refugee quotas themselves reflect calculations of pure international political interest. Iraqi refugee admissions to the US since 2003 have been-for better and worse-inseparable from the broader goals and strategic imperatives of US involvement in Iraq. So long as the mass displacement of Iraqis continues to impact social and political stability in Iraq and her neighbouring states, we can expect US resettlement of Iraqis to continue on a broad scale.

\section{Notes}

1. One hundred and forty-four states are currently signatories to the 1951 Convention, and 145 states are signatories to the 1967 Protocol. See UNHCR's full list of signatory states: UNHCR, States Parties to the 1951 Convention relating to the Status of Refugees and the 1967 Protocol, accessed March 9, 2011, http://www.unhcr.org/protect /PROTECTION/3b73b0d63.pdf.

2. UNHCR, Global Trends 2010, accessed June 6, 2011, http:// www.unhcr.org/4dfa11499.html.

3. Congressional Research Service, "Iraqi Refugees and Internally Displaced Persons: A Deepening Humanitarian Crisis?" (February 13, 2009), accessed June 6, 2011, http:// www.fas.org/sgp/crs/mideast/RL33936.pdf.

4. A majority of Iraqi refugees interviewed by the International Rescue Committee in February of 2011 expressed opposition to repatriation, preferring permanent residency in their Arab host state or international resettlement. International Rescue Committee, "Iraqi Displacement: Eight Years Later Durable Solutions Still Out of Reach" (February 2011), accessed May 16, 2011, http://www.rescue.org / sites/default/files/resource-file/Iraqi $\% 20$ Displacement\%20Eight\%20Years\%20Later.pdf.

5. UNHCR, Note on the Continued Applicability of the April 2009 UNHCR Eligibility Guidelines for Assessing the International Protection Needs of Iraqi Asylum-Seekers (July 2010), accessed May 15, 2011, http://www.unhcr.org /refworld/docid/4c4fed282.html.

6. United Nations Office for the Coordination of Humanitarian Affairs, Regional Response Plan for Iraqi Refugees, accessed May 15, 2011, http://ochaonline.un.org/ humanitarianappeal/webpage.asp? MenuID $=14470$ \&Page $=1932$.

7. UNHCR, Universal Periodic Review: United States of America (April 2010), accessed May 16, 2011, http://www.unhcr .org/refworld/category,POLICY,,USA,4bcd741c2,0.html.

8. US Bureau of Population, Refugees, and Migration, Refugee Admissions Program for the Near East and South Asia (May 6, 2011), accessed May 16, 2011, http://www.state .gov/g/prm/rls/fs2011/162821.htm.
9. US Citizenship and Immigration Services, U.S. Refugee Processing, updated June 3, 2011, accessed June 16, 2011, http://www.uscis.gov/portal/site/uscis.

10. International Rescue Committee, "A Tough Road Home: Uprooted Iraqis in Jordan, Syria and Iraq" (February 2010), accessed May 16, 2011, http://www.rescue.org/sites/default /files/resource-file/IRC_Report_ToughRoad_v6.pdf.

11. Stark double standards in legal protection applied, for example, to the comparative treatment of Haitian vs. Cuban asylum seekers arriving by boat in the southern United States. Audrey Singer and Jill H. Wilson, "From 'There' to 'Here': Refugee Resettlement in Metropolitan America" (The Brookings Institute, September 2006), 1-4, accessed June 11, 2011, http://www.brookings.edu /research/reports/2006/09/demographics-singer.

12. US Department of Health and Human Services, Questions \& Answers-Iraqi Refugees, updated March 6, 2009, accessed May 15, 2011, http://www.acf.hhs.gov/programs /orr/press/Q_A_Iraqi_ref.htm .

13. Ben Sanders and Merrill Smith, "The Iraqi Refugee Disaster," World Policy Journal (New York, NY: World Policy Institute, 2007): 23-28.

14. Meital Waibsnaider, "How National Self-Interest and Foreign Policy Continue to Influence the U.S. Refugee Admissions Program," Fordham Law Review 75 (2006-2007): 398.

15. Sanders and Smith, "The Iraqi Refugee Disaster," 23-28.

16. Volker Perthes, Syria under Bashar al-Asad: Modernisation and the Limits of Change (New York: Oxford University Press, 2004), 48.

17. Nir Rosen, "Flight From Iraq," New York Times Magazine (May 13, 2007).

18. Kathryn Libal, "The Politics of Refugee Advocacy and Humanitarian Assistance," Merip 244 (Fall 2007).

19. Sanders and Smith, "The Iraqi Refugee Disaster," 23-28.

20. Patricia Weiss Fagen, "Iraqi Refugees: Seeking Stability in Syria and Jordan," Center for International and Regional Studies, Occasional Paper No. 1 (2009), accessed April 21, 2011, http://isim.georgetown.edu/publications/20071231 Iraqi_Refugees.pdf, 2.

21. Ashraf al-Khalidi, Sophia Hoffman, and Victor Tanner, "Iraqi Refugees in the Syrian Arab Republic: A Field-Based Snapshot," The Brookings Institute Project on Internal Displacement: Occasional Paper (June 2007), accessed April 21, 2011, http://www.brookings.edu/ /media /research/files/papers/2007/6/11humanrights\%20al\%20 khalidi/0611humanrights_alkhalidi.pdf, 15 .

22. US Government Accountability Office, Iraqi Refugee Assistance: Improvements Needed in Measuring Progress, Assessing Needs, Tracking Funds, and Developing an International Strategic Plan (April 2009), accessed May 16, 2011, http:// www.gao.gov/assets/290/288610.pdf, 10.

23. By the end of 2003, the over-stretched Coalition Provisional Authority was attempting to adjudicate the citizenship and property claims of nearly 60,000 Kurdish returnees in temporary shelters. David Romano, "Whose House 
Is This Anyway? IDP and Refugee Return in Post-Saddam Iraq," Journal of Refugee Studies 18, no. 4 (2005): 10-16.

24. Romano, "Whose House Is This Anyway?"

25. US Federal News Service, "State Department Foreign Press Centre Briefing on Refugee Programs in Iraq, Jordan, and Syria" (Washington, DC: Federal News Service, December 1, 2009).

26. US Department of State, Proposed Refugee Admissions for Fiscal Year 2011: Report to the Congress, accessed June 11, 2011, http://www.wrapsnet.org/LinkClick.aspx?fileticket $=$ Kvk2cfYHNjg\%3d\&tabid=300\&mid=793\&language $=$ en-US, 45 .

27. UNHCR, Global Trends 2010.

28. Sanders and Smith, "The Iraqi Refugee Disaster," 24.

29. Bill Frelick, "Talk to Syria for the Sake of Iraqi Refugees," Huffington Post (October 15, 2007), accessed May 16, 2011, http://www.huffingtonpost.com/bill-frelick/talk-to-syria -for-the-sak_b_68669.html.

30. Sanders and Smith, "The Iraqi Refugee Disaster," 25.

31. US Government Accountability Office, Iraqi Refugees and Special Immigrant Visa Holders Face Challenges Resettling in the United States and Obtaining U.S. Government Employment (March 2010), accessed June 2, 2011, http:// www.gao.gov/assets/310/301555.pdf.

32. The 2001 Act Operation Liberty Shield provided legal basis for the rejection of refugees from countries hosting designated "terrorist" organizations-a category clearly concocted with the beginnings of the "Global War on Terror" in mind. US Department of Homeland Security, Operation Liberty Shield, released March 17, 2003, accessed June 2, 2011, http://www.dhs.gov/xnews/releases/press _release_0115.shtm.

33. US Federal News Service, "Hearing of the United States Commission on Security and Cooperation in Europe" (Washington, DC: Federal News Service, April 10, 2008).

34. Sanders and Smith, "The Iraqi Refugee Disaster," 24.

35. Bill Frelick, "The Human Costs of War: The Iraqi Refugee Crisis," Testimony before the Congressional Human Rights Caucus (November 14, 2007), accessed May 16, 2011, http://www.hrw.org/news/2007/11/14 /human-cost-war-iraqi-refugee-crisis.

36. Reinoud Leenders, "Getting the 'Ladder of Options' Right-The Illusive and Real Security Fallout of the Iraqi Refugee Crisis," Middle East Institute and Fondation pour la Recherche Stratégique (September 15, 2010), accessed April 24, 2011, http://www.refugeecooperation.org /publications/Iraq/01_leenders.php.

37. Human Rights First, "Living in Limbo: Iraqi Refugees and U.S. Resettlement” (December 2010), accessed May 15, 2011, http://www.humanrightsfirst.org/wp-content /uploads/Living-in-Limbo-final.pdf, 2.

38. European Parliament, Resolution on the Humanitarian Situation of Iraqi Refugees (July 12, 2007), accessed May 7, 2011, http://www.unhcr.org/cgi-bin/texis/vtx/refworld $/$ rwmain?docid $=4697795 \mathrm{~d} 2$.
39. 110th Congress of the United States, "Bill Text: S.1651Refugee Crisis in Iraq Act," introduced June 19, 2007, accessed July 4, 2011, http://thomas.loc.gov/cgi-bin/query /z?c110:S.1651.IS:.

40. US Department of State, Bureau of Near Eastern Affairs, Iraq Status Report 2009, 12, accessed June 4, 2011, http:// www.state.gov/p/nea/rls/rpt/.

41. US Department of State, Proposed Refugee Admissions for Fiscal Year 2010: Report to the Congress, accessed June 11, 2011, http://www.state.gov/documents/organization /181382.pdf.

42. US Department of State, "Fact Sheet: Refugee Resettlement Program for Iraqis in Jordan, Egypt and Iraq with U.S. Affiliations" (February 3, 2009), accessed May 15, 2011, http://www.state.gov/g/prm/rls/115888.htm.

43. US Department of State, Proposed Refugee Admissions for Fiscal Year 2010: Report to the Congress, 57.

44. US Citizenship and Immigration Services, U.S. Refugee Processing, updated June 3, 2011, accessed May 16, 2011, http://www.uscis.gov/portal/site/uscis.

45. Overall refugee admissions levels under the Obama administration have begun to approach pre-9/11 levels, a sign of renewed American commitment to "leading by example" with its refugee resettlement program. Admissions levels in FY 2009 were the highest since 1999; 75,000 refugees comprised some 73 percent of UNHCR-referred cases worldwide. United States Department of State, Proposed Refugee Admissions for Fiscal Year 2011: Report to the Congress.

46. Human Rights First, "Living in Limbo," 3.

47. US Department of State, Proposed Refugee Admissions for Fiscal Year 2011: Report to the Congress, 45.

48. Natalie Ondiak and Brian Katulis, "Operation Safe Haven Iraq 2009: An Action Plan for Airlifting Endangered Iraqis Linked to the United States," Center for American Progress (January 2009), accessed May 15, 2011, http://www .americanprogress.org/issues/2009/01/pdf/iraqi_refugees .pdf.

49. US Government Accountability Office, Iraqi Refugees and Special Immigrant Visa Holders Face Challenges Resettling, 1.

50. Human Rights Action and the Human Rights Institute, "Refugee Crisis in America: Iraqis and Their Resettlement Experience" (2010), accessed May 16, 2011, http:// cdm16064.contentdm.oclc.org/cdm/ref/collection /p266901coll4/id/2154, 19-33.

51. For example, Michigan resettlement organizations in 2008 received funding for 300 Iraqi refugees but worked with a caseload of over 1,200. US Government Accountability Office, Iraqi Refugees and Special Immigrant Visa Holders Face Challenges Resettling, 11.

52. Ibid., 11.

53. Ibid., 13.

54. UNHCR, Global Trends 2010, 2.

55. Only 560 Iraqis applied for asylum to the US and Canada in 2009, making up less than 1 percent of the asylum 
seeking population. UNHCR, Asylum Levels and Trends in Industrialized Countries 2010 (March 28, 2011), accessed May 18, 2011, http://www.unhcr.org/4d8c5b109.html.

56. In 2008 nearly 67,000 people crossed into Europe by sea, including Iraqis. US Committee for Refugees and Immigrants, World Refugee Survey 2009: Europe, accessed June 5, 2011, http://www.refugees.org/resources/refugee -warehousing/archived-world-refugee-surveys/2009 -world-refugee-survey.html.

57. Ten thousand Iraqis applied to Europe in 1994, followed by 22,600 in 1996 and 36,000 in 1997. Christina Boswell, "The 'External Dimension' of EU Immigration and Asylum Policy," International Affairs 79, no. 3 (May 2003): 629.

58. International Rescue Committee, 10,000 Refugees from Iraq: A Report on Joint Resettlement in the European Union (May 2010), accessed May 16, 2011, http://www. rescue.org/sites/default/files/resource-file/10\%20000\%20 Refugees\%20from\%20Iraq\%20-\%20Joint\%20Resettlement $\% 20$ in $\% 20$ the $\% 20$ EU\% 20 - \% 20ICMC\%20IRC\%20 report\%20May\%202010\%20-\%20Final.pdf.

59. "Liberalization" and "harmonization" are stated goals of the CEAS regime; "liberalization" refers to improvements in asylum processing and refugee welfare infrastructure, while "harmonization" is defined as the process of making asylum and refugee policies more similar across European states.

60. Eiko R. Thielemann, "Symbolic Politics or Effective BurdenSharing? Redistribution, Side-payments and the European Refugee Fund," Journal of Common Market Studies 43, no. 4 (2005): 815.

61. Peo Hansen, "Post-national Europe-Without Cosmopolitan Guarantees," Race \& Class 50, no. 20 (2009): 26.

62. Satvinder S. Juss, "The Decline and Decay of European Refugee Policy," Oxford Journal of Legal Studies 25, no. 4 (2005): 750-766.

63. UNHCR, Asylum Levels and Trends in Industrialized Countries 2010, 2.

64. European Council on Refugees and Exiles, Five Years on Europe Is Still Ignoring Its Responsibilities towards Iraqi Refugees (March 2008), accessed June 2, 2011, http://www .cir-onlus.org/ECRE_RICERCA_IRAQ.pdf, 2-3.

65. Elspeth Guild, "The Europeanisation of Europe's Asylum Policy," International Journal of Refugee Law 18 (2006): 630-51.

66. European Council on Refugees and Exiles, "Five Years on Europe Is Still Ignoring Its Responsibilities towards Iraqi Refugees," 5.

67. European Parliament, Minimum Standards for the Reception of Applicants for Asylum in the Member States-Assessment (Summary) of the Implementation of the 2003 Directive and Proposals for a Common European Asylum System (CEAS), 2-3 (September 2008), accessed June 6, 2011, http://www.unhcr.org/refworld/pdfid/48d3b8be2.pdf .

68. European Council on Refugees and Exiles, ECRE Memorandum on the Occasion of the Hungarian Presidency of the
EU (January 2011), 6, accessed May 17, 2011, http://www .unhcr.org/refworld/type,COMMENTARY,,,4d357c342,0 .html.

69. Peo Hansen has compared Sweden's resettlement trajectory in the late 2000s with Germany's in the early 1990s, when Berlin's failure to secure broader European support for its uniquely generous resettlement of asylum seekers from the former Soviet Union eventually led to the adoption of far more restrictive policies. Hansen, "Post-national EuropeWithout Cosmopolitan Guarantees," 23-25.

70. European Council on Refugees and Exiles, Five Years on Europe Is Still Ignoring Its Responsibilities towards Iraqi Refugees.

71. Sweden's Prime Minister Frederik Reinfile expressed his frustration with European burden sharing in May 2008, saying, "Sweden has done very much the job and less has been done by others." International Rescue Committee, 10,000 Refugees from Iraq, 14.

72. US Committee for Refugees and Immigrants, World Refugee Survey 2009: Europe, (2009): 3.

73. Also in 2008, Sweden signed an agreement of forced return with the Iraqi government. Assyrian International News Agency, "Council of Europe Demands Sweden Stop Deporting Iraqi Refugees” (July 22, 2010), accessed May 17, 2011, http://www.aina.org/releases/20100721211724.htm.

74. International Rescue Committee, 10,000 Refugees from Iraq, 16.

75. UNHCR, Asylum Levels and Trends in Industrialized Countries 2009 (March 23, 2010), accessed June 5, 2011, http:// www.unhcr.org/4ba7341a9.html.

76. International Rescue Committee, 10,000 Refugees from Iraq, 24.

77. Hansen, "Post-national Europe-Without Cosmopolitan Guarantees," 26.

78. Amnesty Belgique Francophone, Amnesty International's Response to the Commission's Proposal for a Regulation of the European Parliament and of the Council Establishing a European Asylum Support System (April 2009), 1-3, accessed July 3, 2011, http://www.unhcr.org/refworld /pdfid/49edc2cc2.pdf.

79. International Rescue Committee, 10,000 Refugees from Iraq, 24.

80. Thielemann, "Symbolic Politics or Effective Burden-Sharing?", 816.

81. Carl Levy, "The European Union after 9/11: The Demise of a Liberal Democratic Asylum Regime?" National Europe Centre Paper, No. 109 (2003), accessed June 2, 2011, http:// www.gold.ac.uk/media/1.\%20govtandoppLevy.pdf, 7.

82. Laurence Cooley and Jill Rutter, "Turned Away? Towards Better Protection for Refugees Fleeing Violent Conflict," Public Policy Research (September 2007), accessed June 3, 2011, http://birmingham.academia.edu/LaurenceCooley /Papers/144018/Turned_away_Towards_better_protection _for_refugees_fleeing_violent_conflict. 
83. European Parliament, Minimum Standards for the Reception of Applicants for Asylum in the Member States, 4.

84. Emma Haddad, "The External Dimension of EU Refugee Policy: A New Approach to Asylum?" Government and Opposition 43, no. 2 (2008): 197.

85. Europe has also increased security criteria for would-be member states, such that "Europe's" new borders in the event of expansion would remain closely guarded. Christina Boswell, “The 'External Dimension' of EU Immigration and Asylum Policy," International Affairs 79, no. 3 (May 2003).

86. European Council on Refugees and Exiles, ECRE Memorandum on the Occasion of the Hungarian Presidency of the EU (January 2011).

87. Amnesty Belgique Francophone, Amnesty International's Response to the Commission's Proposal, 11.

88. Markus Sperl, “Fortress Europe and the Iraqi 'Intruders': Iraqi Asylum-seekers and the EU, 2003-2007," New Issues in Refugee Research, No. 144 (October 2007): 14.

89. Juss, "The Decline and Decay of European Refugee Policy," 750-66.

90. Levy, "The European Union after 9/11," 21.

91. UNHCR, Convention and Protocol relating to the State of Refugees (July 28, 1951, 189 U.N.T.S. 150), accessed March 9, 2011, http://www.unhcr.org/3b66c2aa10.html.

92. UNHCR, Asylum Levels and Trends in Industrialized Countries 2010.

93. Human Rights Watch, "Stuck in a Revolving Door: Iraqis and Other Asylum Seekers and Migrants at the Greece/ Turkey Entrance to the European Union" (November 2008), 22-23.

94. European Council on Refugees and Exiles, ECRE Memorandum on the Occasion of the Hungarian Presidency of the $E U, 6$.

95. Greece's 2009 Iraqi recognition rate of 0.3 percent is extremely low by world standards. Ibid., 8 .

96. According to the US Committee for Refugees and Immigrants, Greece detained some 6,000 unaccompanied minors in 2009, and deported nearly 1,200 of them. US Committee for Refugees and Immigrants, "World Refugee Survey 2009: Europe” (2009).

97. US Committee for Refugees and Immigrants, World Refugee Survey 2009: Europe.

98. European Council on Refugees and Exiles, ECRE Memorandum on the Occasion of the Hungarian Presidency of the EU.
99. Overseas refugee processing is also the primary resettlement strategy practiced by Australia's Refugee and Humanitarian Program. There were 2,151 Iraqis resettled to Australia via offshore processing in 2010-11. Australian Government, Department of Immigration and Citizenship,

"Fact Sheet 60-Australia's Refugee and Humanitarian Program," accessed March 9, 2012, http://www.immi.gov.au/ media/fact-sheets/60refugee.htm\#e.

100. Haddad, "The External Dimension of EU Refugee Policy: A New Approach to Asylum?”, 196.

101. Guild, "The Europeanisation of Europe's Asylum Policy."

102. International Rescue Committee, 10,000 Refugees from Iraq, 3-5.

103. UNHCR, Background Paper from UNHCR: EU Resettlement (December 12, 2008), accessed June 17, 2011, http:// www.unhcr.org/refworld/docid/496e19392.html.

104. International Rescue Committee, 10,000 Refugees from Iraq, 10.

105. Christina Boswell, “The 'External Dimension' of EU Immigration and Asylum Policy," International Affairs 79, no. 3 (May 2003).

106. European aid to Syria has been particularly impactful, as the United States refuses to directly fund the Syrian state, and Syria in particular suffers from a dearth of foreign money supporting its social service provision to Iraqis.

107. European Council on Refugees and Exiles, ECRE Memorandum on the Occasion of the Hungarian Presidency of the $E U, 7$.

108. Ibid., 8.

109. Haddad, “The External Dimension of EU Refugee Policy: A New Approach to Asylum?”, 199.

110. Singer and Wilson, "From 'There' to 'Here': Refugee Resettlement in Metropolitan America," 1-4.

Chantal Berman is a recent graduate of Brown University, where her honours thesis comparing the Iraqi refugee policies of Syria and Lebanon won the Samuel C. Lamport prize for Best Thesis in International Relations. Chantal has published articles on the international response to the Iraqi refugee crisis for the Middle East Institute's paper series on protracted displacement (refugeecooperation.org) and for Brown University's interdisciplinary study "Costs of War" (costsofwar.org).

(C) Chantal E. Berman, 2011. This open-access work is licensed under a Creative Commons Attribution-NonCommercial 4.0 International License, which permits use, reproduction and distribution in any medium for non-commercial purposes, provided the original author(s) are credited and the original publication in Refuge: Canada's Journal on Refugees is cited. 
(C) Chantal E. Berman, 2011. This open-access work is licensed under a Creative Commons Attribution-NonCommercial 4.0 International License, which permits use, reproduction and distribution in any medium for non-commercial purposes, provided the original author(s) are credited and the original publication in Refuge: Canada's Journal on Refugees is cited. 